\title{
Зміни судин мікроциркуляторного русла шкіри та м'язів у хворих з ішемічною формою синдрому діабетичної стопи
}

\author{
С. М. Діденко ${ }^{1}$, В. Ю. Субботін ${ }^{1}$, О. В. Каленська ${ }^{1}$, Л. В. Каленська ${ }^{1}$, І. М. Савицька ${ }^{2}$, \\ Ю. М. Гупало ${ }^{3}$, О. Є. Швед ${ }^{3}$, Д. Ю. Шаповалов ${ }^{3}$ \\ ${ }^{1}$ Клінічна лікарня «Феофанія» Державного управління справами, м. Київ, \\ ${ }^{2}$ Національний інститут хірургії та трансплантології імені О. О. Шалімова НАМН України, м. Київ, \\ ${ }^{3}$ Науково-практичний центр профілактичної та клінічної медицини Державного управління справами, м. Київ
}

\section{Changes in the microcirculatory bed vessels in skin and muscles of patients, suffering ischemic form of the diabetic foot syndrome}

\author{
S. M. Didenko ${ }^{1}$, V. Yu. Subbotin ${ }^{1}$, O. V. Kalenska ${ }^{1}$, L. V. Kalenska ${ }^{1}$, I. M. Savitska ${ }^{2}$, \\ Yu. M. Hupalo', O. E. Shved ${ }^{3}$, D. U. Shapovalov ${ }^{3}$ \\ ${ }^{1}$ Clinical Hospital «Feofania» of State Directorate for Affairs, Kyiv, \\ ${ }^{2}$ Shalimov National Institute of Surgery and Transplantology, Kyiv \\ ${ }^{3}$ Scientific-Practical Centre of Prophylactic and Clinical Medicine, Kyiv
}

\section{Реферат}

Мета. Виявити характерні зміни кровоносних судин шкіри та м'язів, а також базальних мембран епідермісу і судин у хворих з ішемічною формою синдрому діабетичної стопи (СДС) та провести морфометричну оцінку для визначення ключових критеріїв різних стадій цукрового діабету (ЦД).

Матеріали і методи. Досліджені 24 зразки шкіри та м’язів нижніх кінцівок (НК) хворих з ішемічною формою СДС на тлі стенотично-оклюзійного ураження артерій НК. Проведені морфологічні, імуногістохімічні дослідження для виявлення маркера проліферативної активності Кі-67 та маркера судинного процесу й базальних мембран колагену IV типу. Вимірювали та порівнювали товщину базальних мембран епідермісу та кровоносних судин, діаметр судин гемомікроциркуляторного русла (ГМЦР) шкіри та м’язів, відсоток експресованих базальних кератиноцитів.

Результати. Зміни ГМЦР скелетних м'язів були більш виражені, ніж зміни ГМЦР шкіри, про що свідчили результати розподілу ШИК-позитивних сполук та колагену IV типу в базальних мембранах епідермісу та стінках кровоносних судин.

Висновки. На тлі діабетичної ангіопатії (ДА) у шкірі хворих рівень проліферації кератиноцитів знижувався до 25,8\%.

Збілышення експресії маркера колагену IV типу, супроводжувалось потовщенням базальних мембран епідермісу в 2,7 та кровоносних судин в 3,1 разу.

Накопичення колагену IV типу та глікозованих сполук призводило до звуження просвіту всіх судин, особливо судин ГмЦР. Внутрішній діаметр судин ГМЦР у шкірі зменшувався: артеріол - на 39\%, венул - на 28\%, капілярів - на 49\%. Внутрішній діаметр судин ГМЦР у м’язах також зменшувався: артеріол - на 45\%, венул - на 38\%, капілярів - на 51\%.

У скелетних м’язах звуження просвіту судин ГМЦР було більш виражене, ніж у шкірі, та супроводжувалось більш вираженими патологічними проявами в цих тканинах.

Ключові слова: цукровий діабет; синдром діабетичної стопи; ангіопатія; базальні мембрани; гемомікроциркуляторне русло.

\section{Abstract}

Objective. To reveal characteristic changes in the blood vessels of skin and muscles, as well as in basal membranes of epidermis and vessels in patients, suffering diabetic foot syndrome (DFS) and to conduct morphometric estimation for determination of the key criteria of the diabetes mellitus various stages.

Materials and methods. There were investigated 24 examples of skin and muscles in the lower extremities (LE) of patients, suffering ischemic form of DFS on background of stenotic-Occlusion affection of the LE arteries. Morphological, immunohistochemical investigation for determination of the proliferative activity marker Ki-67 and marker of vascular process and the basal membranes Type IV collagen were conducted. The epidermis basal membranes and the blood vessels thickness, the hemomicrocirculatory bed (HMCB) diameter in skin and muscles were measured and compared, as well as the percent of expressed basal keratinocytes.

Results. Changes in the skeletal muscles HMCB were more severe, than in the skin HMCB, witnessed by results of the PAS-positive compounds of the Type IV collagen in basal membranes of epidermis and walls of the blood vessels.

Conclusion. On background of diabetic angiopathy the keratinocytes proliferation level in the patients' skin have lowered down to $25.8 \%$.

Increase of the Type IV collagen marker expression was accompanied by the basal epidermis membrane thickening in 2.7 and blood vessels - in 3.1 times.

Accumulation of the Type IV collagen and glycosylated compounds have brought to narrowing of lumen in all vessels, particularly in the HMCB vessels. Internal diameter of the HMCB vessels in skin have reduced: arteriols - by $39 \%$, venules - by $28 \%$, capillaries - by $49 \%$ Internal diameter of the HMCB vessels in muscles have reduced also: arteriols - by $45 \%$, venules - by $38 \%$, capillaries - by $51 \%$.

In skeletal muscles the vessels' lumen narrowing in HMCB was more pronounced, than in skin, and was accompanied by more significant pathological signs in these tissues.

Key words: diabetes mellitus; syndrome of diabetic foot; angiopathy; basal membranes; hemomicrocirculatory bed. 
Діабетична ангіопатія (ДА) у хворих з Цд викликає ускладнення, що призводять до інвалідизації та навіть смерті. Проте роль ДА у розвитку СДС досі повністю не визначена. ДА викликає структурні зміни в тканинах НК, зокрема, у шкірі та скелетних м'язах. Визначити характер змін можна за допомогою морфологічних та імуногістохімічних досліджень [1, 2], результати яких є важливі для визначення тактики подалышого лікування.

Епідерміс та сосочковий шар у хворих з Цд зазнають виражених змін через порушення обміну речовин і особливо пошкоджуються внаслідок порушень кровопостачання та дисбалансу метаболічних процесів [3]. В епідермісі відбуваються дистрофічні зміни, уповільнюються процеси відновлення його клітин. Базальна мембрана, яка створює мікросередовище і виконує структурну та регуляторну функції [4], теж перебудовується. Змінюються й базальні мембрани кровоносних судин, особливо сосочкового шару. Потовщення базальної мембрани при Щд є переважно наслідком уповільненої деградації ії компонентів, а не посиленого синтезу $[1,5]$.

Коли змін зазнає сосочковий шар, розташований під епідермісом, це також впливає на метаболічні процеси в базальних клітинах епідермісу та на стан базальної мембрани. У свою чергу в епідермісі не тільки змінюється рівень васкуляризації, а й підвищується проникливість стінок кровоносних судин, що пов'язано з глікозуванням базальних мембран [6, 7].

У м'язах при џд погіршується кровопостачання через значне зменшення діаметру артеріол і венул, зменшення кількості функціонуючих гемокапілярів, звуження їх просвіту та зменшення прохідності. 3 прогресуванням хвороби потовщується та втрачає еластичність і пластичність базальна мембрана капілярів, а за ії межами розвивається густа сітка колагенових волокон [8]. Деструктивні процеси призводять до атрофічних змін у м'язових волокнах.

За допомогою імуногістохімічних реакцій можна виявити маркер клітинної проліферації $\mathrm{Ki}-67$ для визначення рівня відновних процесів в епідермісі [9] та колаген IV типу, який є маркером основних змін у базальній мембрані епідермісу й судин. За результатами морфологічних та імуногістохімічних досліджень можна оцінити функціональний стан клітин шкіри та м'язів.

Мета дослідження: виявити характерні зміни кровоносних судин шкіри та м'язів, а також базальних мембран епідермісу й судин у хворих з ішемічною формою СДС та дати їм морфометричну оцінку для визначення ключових критеріїв різних стадій Цд.

\section{Матеріали і методи дослідження}

Для проведення досліджень підготовлені 24 парафінові блоки зразків шкіри та м'язів хворих з ішемічною формою СДС на тлі стенотично-оклюзійного ураження артерій НК, яким проведено лікування в Центрі судинної хірургії Клінічної лікарні «Феофанія» протягом 2014 -2017 pp.

Для порівняння використані зразки шкіри пацієнтів, які не мали системних захворювань (контрольні).

Матеріал для досліджень отримували під час операційних втручань $з$ дотриманням правил етики і деонтології без морально-правових порушень згідно 3 по- ложеннями Конвенції Ради Європи «Про захист прав і гідності людини щодо застосування досягнень біології та медицини: Конвенція про права людини та біомедицину» (1997).

Парафінові зрізи товщиною 5 мкм виготовляли за допомогою мікротома Leica 2025. Частину їх забарвлювали гематоксиліном та еозином, пікрофуксином за ван Гізоном. Для оцінки стану базальних мембран та порушень обміну в тканинах використовували метод 3 Шифф-йодною кислотою (ШИК-реакцію) за МакМанусом ї контроль з амілазою [10].

Імуногістохімічні реакції проводили за стандартними протоколами [11] з використанням моноклональних мишачих та кролячих антитіл.

Використані такі антигени: Кi-67 - маркер проліферативної активності; колаген IV типу - маркер судинного процесу, який, крім того, виявляють в базальних мембранах

Після депарафінування та промивки зрізів у дистильованій воді демаскували антигени з використанням 10\% демаскувального буфера (К043), витримували зрізи протягом 40 хв від моменту закипання води в пароварці при температурі $98^{\circ} \mathrm{C}$ в режимі «Пар», потім охолоджували.

Зрізи також витримували в трьох порціях буфера для промивання (Wach ДМ-83, 50 мл буфера та 950 мл дистильованої води) по 3 - 4 хв. Блокували ендогенну пероксидазу у 3\% розчині перекису водню протягом 10 хв. Здійснювали інкубацію антитіл у рекомендованих виробником розведеннях протягом 30 хв при кімнатній температурі у вологій камері. Після подальшої обробки і поміщення зрізів у бальзам препарати досліджували за допомогою світлооптичного мікроскопа Leica DM500.

Товщину базальної мембрани епідермісу на препаратах у 6 випадкових полях зору визначали після ШИКреакції та імуногістохімічного забарвлення антитілами до колагену IV типу при збільшенні ×400. Порівнювали отримані дані.

Внутрішній діаметр кровоносних судин у сосочковому шарі шкіри та поперечносмугастих м'язах вимірювали після імуногістохімічного забарвлення антитілами до колагену IV типу при збільшенні ×400. Також досліджували 6 випадкових полів зору. Фотодокументування здійснювали за допомогою цифрової камери Leica ICC50 HD, а морфометричний та статистичний аналіз - за допомогою комп'ютерної програми «Paradise». Статистичну достовірність отриманих даних визначали за допомогою t-критерію Стьюдента [12]. Всі статистичні дані вважали достовірними при $\mathrm{p}<0,05$.

\section{Результати}

Дослідженнями препаратів шкіри НК хворих з ЦД виявлено атрофію епідермісу з проявами вакуолярної дистрофії кератиноцитів росткового шару. В окремих зразках епідерміс характеризувався значною десквамацією, залишались 2 - 3 ряди кератиноцитів, епідермальнодермальні межі були згладжені. Рівень проліферації епітеліальних клітин у порівнянні 3 контрольними зразками був знижений до 20 - 26\%, про що свідчили результати досліджень зразків, забарвлених антитілами до Кі-67 (рис. 1). В епідермісі вміст імунопозитивних клітин становив $(25,8 \pm 1,8) \%(n=24, p<0,05)$. 


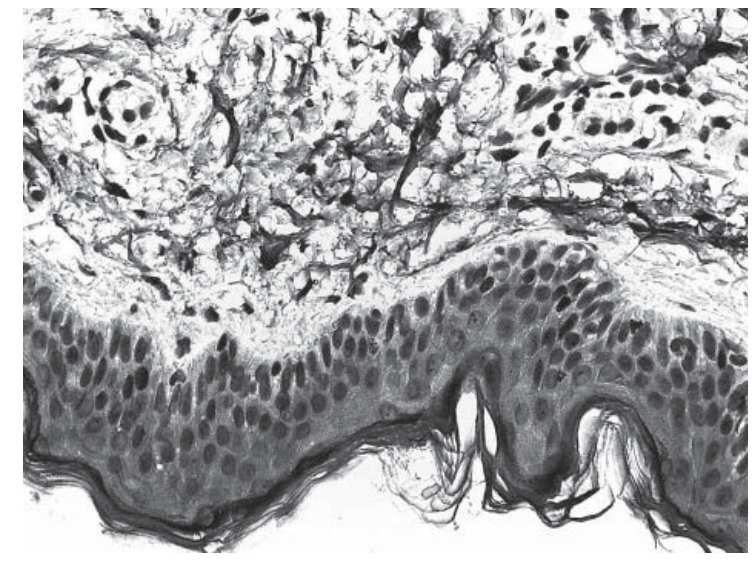

Рuc. 1. Мiкрофото.

Знижена експресія маркера проліферацї Кі-67 в епідермісі. цмунопероксидазна реакиія. $36 . \times 400$.

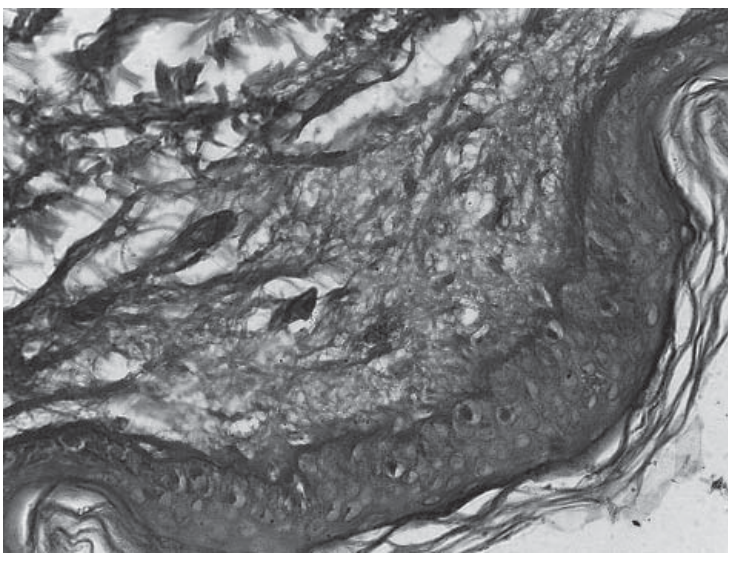

Puc. 2. Мiкрофбото.

Збільиена товщина базальноїмембрани епідермісу. ШИК-реакиія. 3б. ×400.

Товщина мембрани епідермісу була збільшена у 2 - 3 рази, у деяких зразках - розпушена із збільшенням товщини у 4 - 4,5 разу (рuс. 2). Показники, виміряні на препаратах після ШИК-реакціі, були вищі, ніж показники, виміряні на препаратах після імуногістохімічних реакцій на виявлення колагену IV типу, що свідчило про підвищений рівень глікозованих сполук у базальній мембрані.

У контрольних зразках шкіри товщина базальної мембрани епідермісу становила $(1,13 \pm 0,09)$ мкм, при ЦД після ШИК-реакції - $(3,49 \pm 0,41)$ мкм, після імуногістохімічної реакції на виявлення колагену IV типу $(3,07 \pm 0,37)$ мкм.

У сосочковому шарі шкіри спостерігали помірний набряк та ущільнення колагенових волокон. Ущільнення та збільшення діаметру колагенових волокон відзначали по всій довжині сітчастого шару з проявами фіброзу. Стінки всіх судин ГМЦР були потовщені, навіть капілярів, переважно через збільшення вмісту колагену IV типу, відмічено збільшення товщини їх базальних мемб-

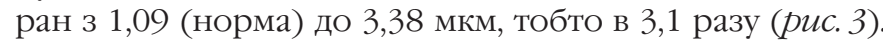
Внутрішній діаметр всіх судин був зменшений: артеріол - на 39\%, венул - на 28\%, капілярів - на 49\%. Крім того, був збільшений вміст інших типів колагену не тільки у внутрішній, а й в інших оболонках судин, що виявля-

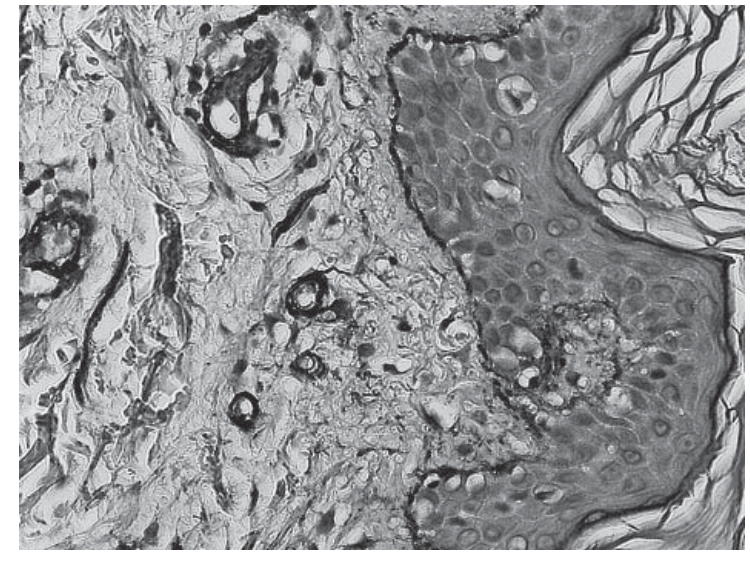

Puc.3.мікрофото.

Експресія колагену IV типу. Потовщення базальноїмембрани епідермісу та кровоносних судин. 3б. ×400.

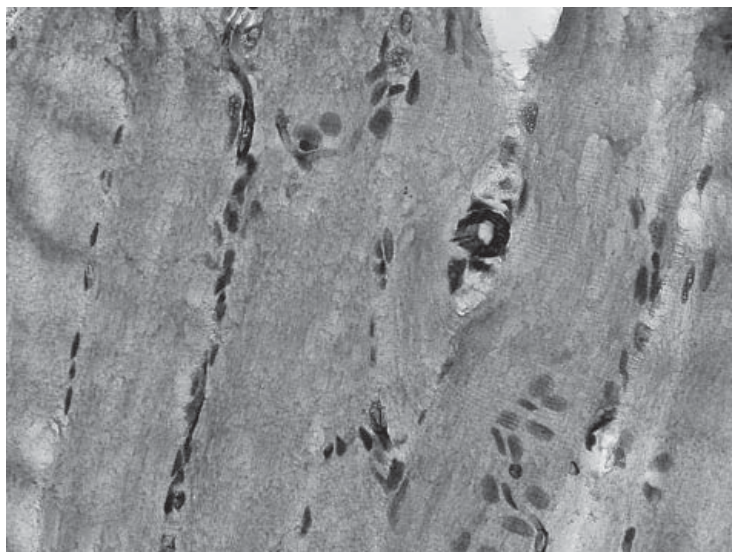

Puc. 4. Мiкpoøomo.

Експресія колагену IV типу. Змениення кількості відкритих капілярів. Потовщення базальних мембран кровоносних судин. 3б. $\times 400$.

ли забарвленням за ван Гізоном. Часто спостерігали вогнища лімфоцитарної інфільтрації навколо кровоносних судин, розташовані переважно в сітчастому шарі на межі з сосочковим, капіляри та вени на окремих ділянках сітчастого шару були розширені, заповнені лейкоцитами 3 невеликою кількістю еритроцитів (лейкоцитарні стази), на інших ділянках діаметр судин ГМЦР був значно зменшений. Артерії середнього калібру були склерозовані, деякі - облітеровані.

В скелетних м'язах відзначали набряк перимізію, переважно закриті капіляри (здавлені набряком строми та м'язових волокон), щільність їх була значно зменшена (рис. 4) і становила 27\% від щільності капілярів у м'язовій тканині контрольних зразків, зменшений був і діаметр капілярів у середньому на 51\%, крім того, в ГМЦР м'язів спостерігали зменшення кількості артеріол, їх діаметр був зменшений на 45\%, а венул - на 38\%.

\section{Обговорення}

Спостерігали склеротичні зміни стінок артерій переважно середнього калібру, атрофію гілочок нервових волокон. У ГМЦР м'язів прояви дисциркуляції супроводжувались стазами, крововиливами, вогнищами гемота плазморагії з набряком строми. У м'язових волокнах відзначали контрактури, фрагментацію окремих во- 
локон, на деяких ділянках - їх деструкцію та міолізис. Також у значній частині м'язових волокон спостерігали ішемічні зміни, склероз та набряк стінок артерій м'яза, склероз або облітерацію деяких судин, строма м'язів мала ознаки ліпоматозу. Зміни ГМЦР скелетних м'язів були більш виражені, ніж зміни ГМЦР шкіри, про що свідчив розподіл ШИК-позитивних сполук та колагену IV типу в базальних мембранах епідермісу та стінках кровоносних судин.

\section{Висновки}

1. Шляхом застосування морфологічних та імуногістохімічних методів виявлені морфофункціональні зміни клітин шкіри та м'язів на тлі ДА. У шкірі хворих 3 Цд рівень проліферації кератиноцитів знижувався до $25,8 \%$.

2. Встановлено збільшення експресії маркера колагену IV типу, що супроводжувалось потовщенням базальних мембран епідермісу в середньому в 2,7 та кровоносних судин у 3,1 разу. Накопичення колагену IV типу призводило до звуження просвіту всіх судин, особливо судин ГМЦР, окремих - аж до повної облітерації.

3. На тлі ДА у шкірі та м'язах через трофічні порушення регенераційної здатності знижувалась швидкість проліферації клітин епідермісу, виникали порушення внутрішньоклітинної регенерації м'язових волокон та сполучнотканинних структур м'язів. Цей процес безпосередньо пов'язаний із звуженням просвіту судин у шкірі та м'язах. Внутрішній діаметр судин ГМЦР у шкірі зменшувався: артеріол - на 39\%, венул - на 28\%, капілярів - на 49\%. Також зменшувався внутрішній діаметр судин ГМЦР у м'язах: артеріол - на 45\%, венул - на 38\%, капілярів на $51 \%$.

4. У скелетних м'язах звуження просвіту судин ГМЦР було більш виражене, ніж у шкірі, що супроводжувалось більш вираженими патологічними проявами.

\section{References}

1. Udovichenko OV, Tokmakova AJu. Diabeticheskaja mikroangiopatija v geneze sindroma diabeticheskoj stopy Saharnyj diabet. 2001;2:148. [In Russian].

2. Gorshunova GN, Valiullin VV. Morfologicheskie izmenenija kozhi pri diabeticheskoj angiopatii. Zhurnal anatomii i gistopatologii. 2012;1(3):44-6. [In Russian].

3. Ametov AS. Saharnyj diabet i serdechno-sosudistye zabolevanija Russkij medicinskij zhurnal. 2014;13:954. [In Russian].

4. Contreras I, Reiser KM, Martinez N. Effects of aspirin or basic amino acids on collagen cross-links and complications in NIDDM Diabetes Care. 1997;20(5):832-5.

5. Banks W, Bale E, White F, Anat J. Morphometric studies of epidermaldermal junctions in the rat ear: some effects of experimental friction an epidermis and anchorning friction. 1984;139(3):425-35.

6. Balabolkin MI. Rol' glikirovanija belkov, oksidantnogo stressa v patogeneze sosudistyh oslonenij pri saharnom diabete. Saharnyj diabet. Materialy Vtorogo diabeticheskogo kongressa. 2002;4:8-16. [In Russian].

7. Emel'janov V.V. Metabolicheskie faktory uskorennogo starenija organizma u bol'nyh saharnym diabetom 2 tipa i ih korrekcija: avtoref. dis. ...kand. med. nauk. - Cheljabinsk. 2007; 24 p. [In Russian]

8. Blanpain C, Lowry W, Pasolli H. Canonical notch signaling functions as a commitment switch in the epidermal lineage Genes Dev. 2006;20:3022-35.

9. Baum H, Meurer I, Unteregger G. Ki-67 antigen expression and growth pattern of basal cell carcinomas Arch. Dermatol Res. 1993;285(5):2915.

10. Prophet EB, Mills B, Arrington JB, Sobin L. Laboratory Methods in Histotechnology. Institute of Pathology. Washington, 1994. 274 p.

11. Petrov SV, Rajhlin NT. Rukovodstvo po immunohimicheskoj diagnostike opuholej cheloveka pod redakciej. 3 izdanie dopolnennoe i pererabotannoe. Kazan': Izd-vo «Titul»; 2004. 456 p. [In Russian].

12. Avtandilov GG. Medicinskaja morfometrija. Rukovodstvo. Moskva: Medicina; 1990. 384 p. [In Russian]. 